資料

\title{
Ice Cores: Record of Past Environment (Climate) and Future Predication
}

\author{
R. Yamada*, G. Tao*, J. Zheng**, R. Kojima* \\ Y. Fujikawa***, T. Sasaki*** and A. Kudo***
}

\begin{abstract}
Studies on ice cores drilled in Antarctic, Greenland and Canadian Arctic ice caps provide the environmental composition and the climate in the past. This information and further study will help in the understanding of the basic natural processes and the extent of human impact on the environment and climate. This will eventually enable us to predict the future of the environment. This review summarizes the state of the art methodologies used in ice core studies, with highlights on the recent studies in this group.
\end{abstract}

\section{Introduction}

During the past few decades, great efforts have been devoted to the investigation of various constituents in the successively dated snow and ice layers deposited in the central areas of the large Antarctic ${ }^{1)}$, Greenland ${ }^{2)}$, Canadian Arctic ${ }^{3)}$ and other ice caps ${ }^{4,5}$. These layers retain unique frozen undisturbed archives of the past environmental changes in the composition of the atmosphere of our planet and its climate. Since gases from both natural and human activities and micro particles from large scale dust storm, ocean splash, volcanic eruptions and biological activities et al. are distributed over the world via global circulation system, their contents in the ice/snow reflect the environmental composition and the climate at the time when the original snowfall took place. Comparing with other recognized global sources of paleo-environmental information, such as marine sediments, lake and bog deposits and tree rings, snow/ice deposits are of particular merit because of their high time

* Nagaoka Institute of Snow and Ice Studies

* * Institute for Chemical Processes and Environmental Technology, National Research Council of Canada

* * * Research Reactor Institute, Kyoto University resolutions, little disturbance and long time record.

Ice cores, obtained by drilling deep below the surface of ice sheets and glaciers in the above areas and elsewhere, have provided scientists with a wealth of fascinating and imposing results. The isotopic composition of the ice tells us about the varying temperature on the ice-sheet surface at the time when the original snow was produced; gases trapped as the snow turned to ice tell us about changing atmospheric chemistry and concentrations of greenhouse gases such as carbon dioxide and methane; dust layers in the ice tell us about the storminess of the Earth and dustiness of the atmosphere; and concentrations of contaminants, such as heavy metals and radio nuclides tell us about the natural state of the environment, global transport systems and the extent of human impact. This precious information will eventually enable us to reconstruct the environmental (climatic) profiles of the past, understand the processes that cause the environment (climate) to change and predict its future.

Drilling down to depths of up to several kilometers at remote inhospitable sites is a formidable challenge. Of prime importance are the 
Figure 1. Location of Ellesmere Island, NWT, Canada. $\boldsymbol{\Delta}$, Agassiz ice cap. (After Kudo et al. ${ }^{14)}$.)

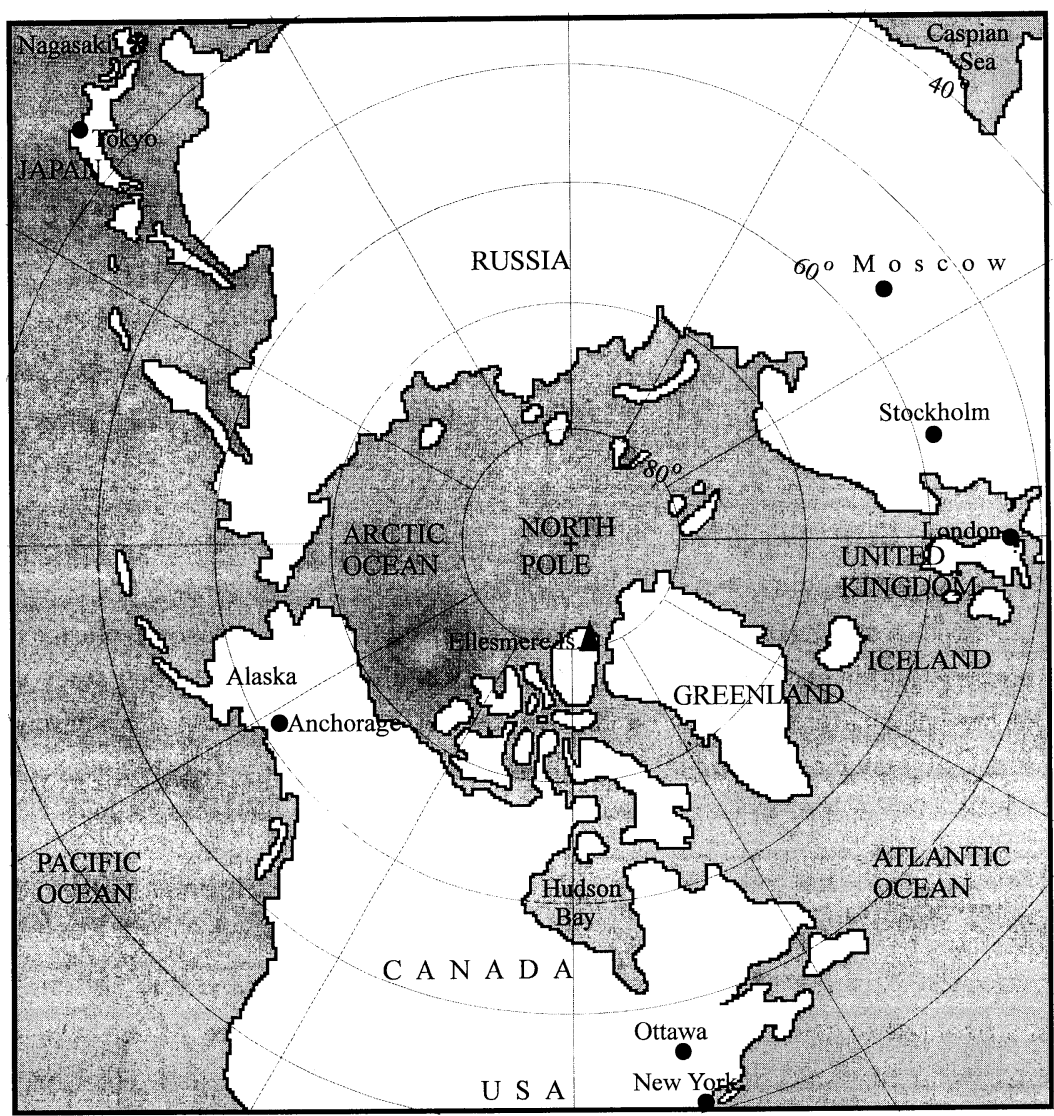

logistical and engineering skills required for drilling in the ice. It was successfully faced only by a handful of institutes, mainly under international cooperative programs. A number of ice cores have been extracted from numerous ice caps and cold glaciers over the world. Antarctica and Greenland are the two most active regions for ice core drilling and study. The physical and chemical environments of Antarctica and Greenland share some similarities but are different, which can be used to investigate, for example, origin of contaminant sources such as locations of volcanic eruptions. Ice cores from both Antarctica and Greenland have produced an abundance of valuable information including the last great climatic transition from Wisconsin to Holocene.

However, ice core drilling in these areas is very expensive. A much cheaper and more accessible alternative is the Canadian Arctic ice caps. These ice caps preserve from thousands to 100 thousands years ice records, depending upon their locations. They provide very reasonable information on environmental changes with a more reasonable cost. Therefore, ice caps in Canadian Arctic, such as Agassiz Ice Cap (Fig. 1), have been intensively investigated for the last two decades. Other ice cores have also been extracted from cold glaciers located at temperate latitudes, such as Dme du Goter in the Alps ${ }^{4)}$ and Mount Logan in Alaska ${ }^{5)}$.

\section{Analytical Methodologies}

In order to unveil the secrets of the past environment (climate), several methodologies have been used to investigate isotopic, physical and chemical parameters of the ice cores. The determination of ${ }^{2} \mathrm{H} /{ }^{1} \mathrm{H}$ and ${ }^{18} \mathrm{O} /{ }^{16} \mathrm{O}$ isotopic ratios in ice cores by specially devised mass spectrometer allows us to reconstruct past temperature changes 
over glacial-interglacial cycles because the isotopic ratios have a linear correlation versus temperature in the temperature range of polar ice caps ${ }^{6-8)}$. They are also used to estimate past accumulation (precipitation) changes and the age of the ice with respect to depth. In addition, they can give additional information about the origin of polar precipitations.

The electrical conductivity measurement (ECM) is a fast, simple and high-resolution method that can be made along the full length of the core in the field as they are obtained ${ }^{9,10)}$. The direct-current electrical conductivity of ice depends on its acidity and it is routinely used to find volcanic events, which in turn can be used to date the specific layers of ice cores and highlight cores of interest for further sampling. ECM can also indicate changes in climate. Ice formed in cold, dusty periods has a high concentration of alkaline dust which significantly reduces the conductivity compared to warmer, less dusty periods.

Gas chromatography is usually used for the analysis of ice bubbles, such as greenhouse gases, carbon dioxide and methane, after extraction from the ice ${ }^{11,12)}$. It is a unique tool for the reconstruction of past greenhouse gas concentrations and the understanding of sharp climatic events that happened during the last hundreds of thousands years. The data also have a potential analogy with a future greenhouse warming in terms of speed and amplitude.

The measurement of radio nuclides in the polar ice can be used for snow dating and snow accumulation rate measurements ${ }^{13)}$, and for the studies on global transport process ${ }^{14)}$. Ultra-sensitive methods, including inductively coupled plasma mass spectrometry ${ }^{15,16)}$, laser-excited atomic fluorescence spectrometry ${ }^{17)}$ and differential pulse anodic stripping voltammetry ${ }^{18)}$, are used for the determination of heavy metals in ice cores which indicate the natural state of the atmosphere and assesses the extent of human impact.

\section{Dating of Snow and Ice}

The prerequisite in the study of ice cores is the accurate determination of the age of the specimens. Various methods have been used to provide dating of depth profiles. It is generally possible to count annual layers visually to obtain excellent dating, particularly in the sites where the amount of snow precipitation is large ${ }^{19}$. The dating of ice layers based on the seasonality of the stable isotope content ${ }^{20)}$ has been applied to numerous ice cores.

Other parameters, including electrical conductivity ${ }^{10,21)}$, laser light scattering of dust ${ }^{22,23)}$, major anions and cations ${ }^{24,25)}, \mathrm{H}_{2} \mathrm{O}_{2}{ }^{26)}$, and ${ }^{14} \mathrm{C}{ }^{27)}$ plus ice dynamics modeling ${ }^{28)}$ have also been used to develop the depth/age relationship for different purposes. Some large and well documented past atmospheric perturbations can also be used as "reference horizons". For instance, the spread of radioactive debris over the planet has served to date the recent snow layers ${ }^{14,29}$. Similarly, by their $\mathrm{SO}_{2}$ emissions, large magnitude volcanic eruptions, such as the Tambora eruption in 1815 and the Laki eruption in 1783, have provided numerous reference horizons in polar ice cores ${ }^{30,31)}$. Generally, various parameters, depending on location where the data is achieved, are useful in establishing the snow layer stratigraphy, and the dating accuracy is greatly improved when several parameters are considered together.

It is a desirable practice to quickly locate some of historical events and/or reasonably estimate snow/ice age on site so that further sampling and/or sub-sampling could be undergone. Therefor, ECM is of its importance due to its fast, simple and high resolution characteristics even though it has some serious limitations. Events like large volcanic eruptions and dramatic climatic changes like Wisconsin/Holocene can be located a few minutes after ice cores are recovered with ECM method.

Recently, Zheng et al. ${ }^{10)}$ measured the electrical conductivity of four Agassiz ice cores, Ellesmere 
Island, NWT, Canada. The ice core site is shown in Fig. 1. The authors set the time scale based on theory and measured layer thickness. The time scale was tuned using volcanic acid layer stratigraphy. The acid stratigraphy was detected using the ECM method and the dates were assigned using known volcano eruptions (Katmai at $\mathrm{AD}$ 1912, Laki at AD 1783 and AD 1259 eruption) and the dates given from the Crete (central Greenland) ice cores, as demonstrated in Fig. $2{ }^{10,32)}$. The precision of the time scale used is \pm 5 years over the last 800 years.

Apparently, averaging or stacking all the Agassiz ECM records could reduce the local noise due to drifts and melt, as it does for other ice core variables. Fig. 3 shows the five -year averages for ECM1, ECM2, ECM3 and ECM A84 with a 1-cm resolution, together with the correlation-optimized average melt layer percentage and $\delta^{18} \mathrm{O}$ time series ${ }^{3,10,33)}$. ECM1, ECM2 and ECM3 data were compiled with a PC for $100 \mathrm{data} / \mathrm{cm}$ of ice cores. The time scale back to about 7500 before present (BP) there is based on models and tuned by correlating major ECM events between Agassiz and Greenland cores. To reduce noise, the A84 and A87 series were added. The $1-\mathrm{cm}$ data is adequate for such temporal resolution for the most recent 7000 years of the Holocene and the sharp $\delta^{18} \mathrm{O}$ transition at the end of the Ice Age was assigned to the GRIPII/GISP2 age of 11,550 years BP. The authors concluded that cores can be crossdated very accurately using all the variance

Figure 3. Holocene plots of five-year averages of ECM1 (A93.1), ECM2 (on a cut surface of A93.1) ECM3 (A93.2) and 10 year averages of A84 ECM. The $\delta^{18} \mathrm{O}$ and summer melt records from A84, A87 averaged together are also presented. Period between 7,000 BP and 11,550 BP has not been scientifically confirmed.(After Zheng et al. ${ }^{10)}$, Koerner et $\mathrm{al}^{3)}$ and Fisher et $\mathrm{al}^{\left.3{ }^{33}\right)}$ )

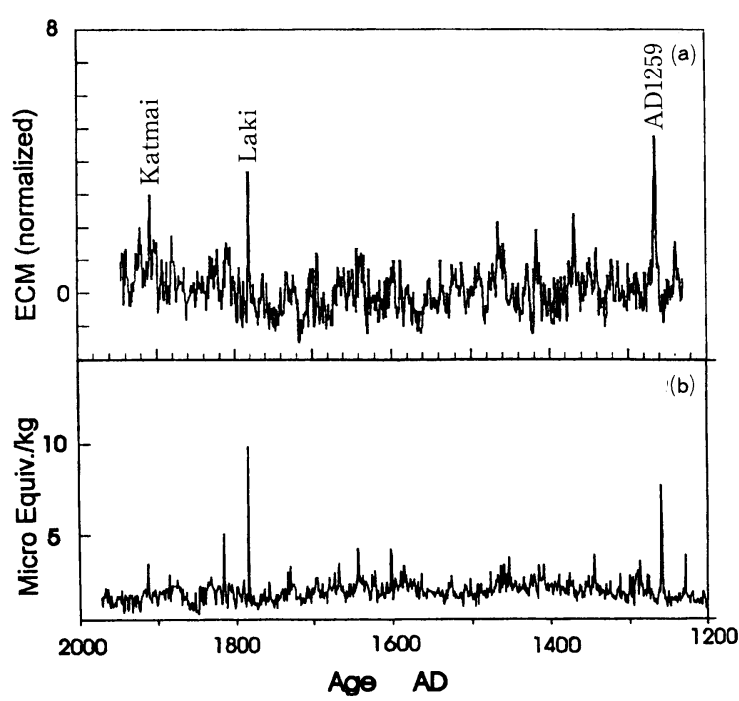

Figure 2. (a) Simple direct averages of normalized ECM series, (A84, A93.2, A93.1) solid line and (A84, A93.2, A93.1, A77) light line. A77, A84, A93.1 and A93.2 refer to the bore hole locations by the year they were drilled; (b) One year averages of ECM from Crete, Greenland (After Zheng et al. ${ }^{10)}$ and Clausen et $\mathrm{al}^{3{ }^{32}}$.)
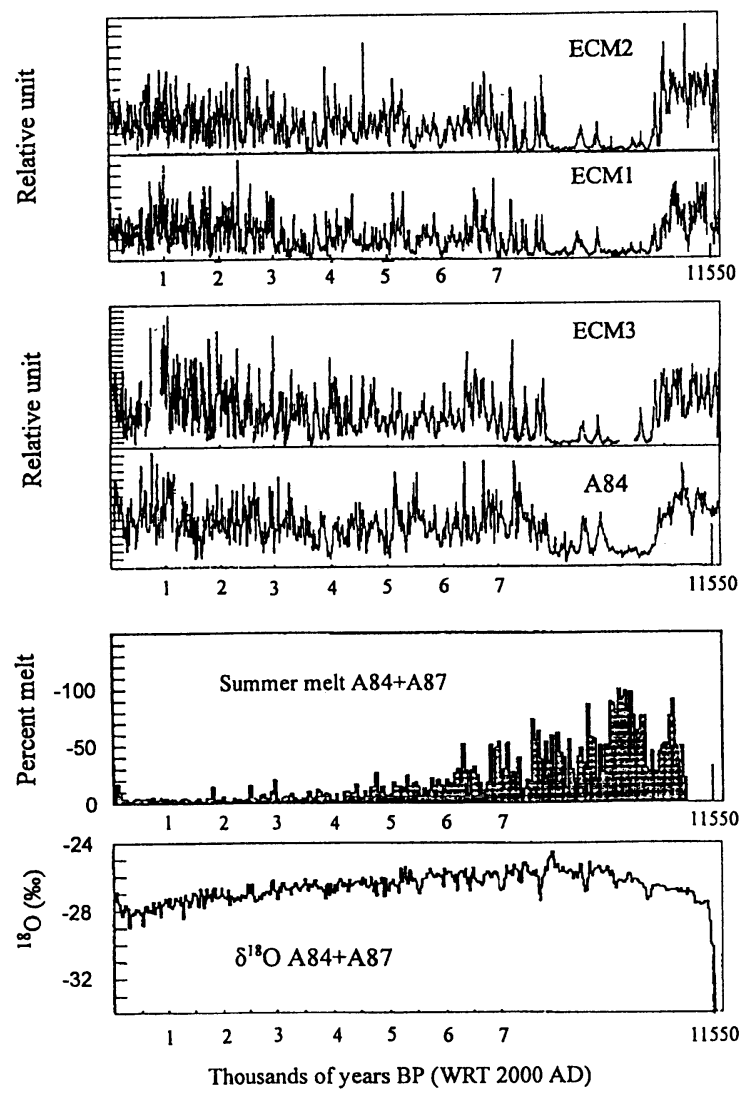
in the ECM series even if only the largest peaks can be reliably used as independent time-marker.

\section{Recent Advances on Ice Core Studies}

The prime importance of the ancient climate change has spurred considerable efforts to extract deep ice cores from Greenland, Antarctica, Canadian Arctic and elsewhere. The results obtained from these ice cores have produced remarkable advances in our understanding of the evolution of Earth's environment (climate).

The most prominent results perhaps come from the recent cooperative works by European Greenland Ice Core Project (GRIPII) and U.S. and Greenland Ice Sheet Project (GISP2) teams ${ }^{2,34}$ ). In the event, the two records from the over $3000-\mathrm{m}$ ice cores drilled $28 \mathrm{~km}$ apart are virtually identical back to 110,000 years ago ${ }^{6,9)}$, showing a stable Greenland climate during the Holocene. The records also confirm beyond doubt the existence of a series of remarkable rapid climate oscillations during the last glacial, which ended about 11,550 years ago. These abrupt changes of perhaps 5 to $10{ }^{\circ} \mathrm{C}$ or more occurred over mere decades, sometimes even during as little as a few years. These interstadial events are probably the most striking features of the Greenland ice-core results.

Similar temperature excursions have now been deduced for the surface of the north Atlantic Ocean from the evidence of deep ocean cores, possibly related to fluctuations in the extent of the polar atmospheric cell and the polar front ${ }^{35)}$. However, in the bottom $10 \%$ of the two cores, the records diverge, and structural disturbances in the ice first become apparent ${ }^{6,9)}$. Detailed comparative studies of these features in the two cores have since been made, but until now have proved inconclusive.

For ice over 110,000 years old, the new bipolar data for the gases, together with more evidence from joint detailed comparisons of the structural properties of the cores, now make an overwhelming case that both cores have suffered stratigra- phic disturbance. Therefore, what had appeared to be sudden cold events in the Eemian seen in the GRIPII core are most probably artifacts caused by flow disturbances ${ }^{36}$.

It had been thought that these unexpected features might indicate that the relative stability of our climate over the past several thousand years is abnormal, even for warm parts of the glacial cycle. The rather worrying implications prompted a search of other high-resolution records of this important distant analogue of modern climate, but produced no persuasive acceptance. In order to identify and characterize the genuine Eemian ice in the Greenland ice, physical modeling is starting to identify some of the factors that may have disturbed the ice much further away from bedrock than hitherto encountered ${ }^{37,38)}$. Substantial rheological differences have been discovered between glacial and interglacial ice that could promote folding or boudinage ${ }^{39}$. In order to obtain a reliable record, the European team has commenced another deep-drilling project in Greenland, about $340 \mathrm{~km}$ northwest of the two earlier drill sites. Layers older than $110 \mathrm{kyr}$ at the new location are thought to be higher above the bedrock than those at the previous bore positions. Therefore, distortions from the flow of ice are less likely to be acute.

High resolution measurements of two atmospheric gases, $\mathrm{CH}_{4}{ }^{12)}$ and $\delta^{18} \mathrm{O}$ of $\mathrm{O}_{2}{ }^{41,42)}$ trapped in the ice have allowed convincing stratigraphic linking of records from the GISP2, GRIPII and Vostok, Antarctica, cores back to $150 \mathrm{kyr}$ ago. Because the global atmosphere mixes rapidly, the makeup of methane everywhere is almost the same. Its long period fluctuations are identified and matched in all the cores. Similarly $\delta^{18} \mathrm{O}$ of $\mathrm{O}_{2}$ constitutes an independent global stratigraphic marker.

Prospects of making the long-awaited connection between the ice-core records and the records from marine sediments came much closer when the new high-resolution data on $\delta^{18} \mathrm{O}$ from Summit, Greenland and Vostok, Antarctica were 
shown to correlate closely both with the $\delta^{18} \mathrm{O}$ deep sea record and with the summer insolation at $65^{\circ} \mathrm{N}$ through the past 100,000 years ${ }^{41,42)}$. Interestingly, the Greenland ice cores demonstrate that the $\mathrm{CH}_{4}$ concentration of the atmosphere increase during each interstadial event ${ }^{12}$. The higher $\mathrm{CH}_{4}$ levels in the ice indicate that the tropical wetlands must have expanded during interstadial times. Measurements of another greenhouse gas, $\mathrm{CO}_{2}$ ${ }^{42,43)}$, and the content of air trapped in GISP2 ice formed have also shown that large, rapid variations exist during each interstadial event. The concentration of $\mathrm{CO}_{2}$ in trapped air varies during cold periods to as much as $200 \mathrm{ppm}$ higher during warm periods ${ }^{43)}$.

Determination of other isotopic and chemical constituents in ice cores also provides rich information and help us understand the past environment (climate). Volcanic aerosol records from GRIPII and GISP2 ice cores, which are based on the continuous measurement of $\mathrm{SO}_{4}{ }^{2-}$, is the most comprehensive means available to reconstruct chronologies of past eruption, suggesting a very strong relationship between explosive volcanism and effects of climate change ${ }^{44}$. It is clearly indicated that peaks of ${ }^{36} \mathrm{Cl}{ }^{45}$ ) and ${ }^{10} \mathrm{Be}{ }^{46)}$ can be viewed as a global time marker and therefore used for synchronization of paleoclimatic time series.

Results on phase partitioning of $\mathrm{Ca}, \mathrm{Fe}, \mathrm{K}$ and $S{ }^{47)}$ along several sections of different climatic regimes of the GRIPII ice core show that the distribution of these elements between the soluble and insoluble phases changed with climatic regimes. Other elements such as $\mathrm{Pb}, \mathrm{Cd}, \mathrm{Hg}, \mathrm{Bi}$, $\mathrm{Cu}, \mathrm{Cr}, \mathrm{Mn}$, et al., in the ice and snow from Greenland, Antarctica and elsewhere, have also been analyzed, which revealed the past and recent changes in the large-scale tropospheric cycles $15-18,48-50)$

It is concluded that human activity has led to an increase in the concentrations of most element during recent centuries both in Antarctica and in Greenland. Evidence of the presence of carcinogenic compounds, such as polycyclic aromatic hydrocarbons ${ }^{51)}$ is also found in the polar atmo-

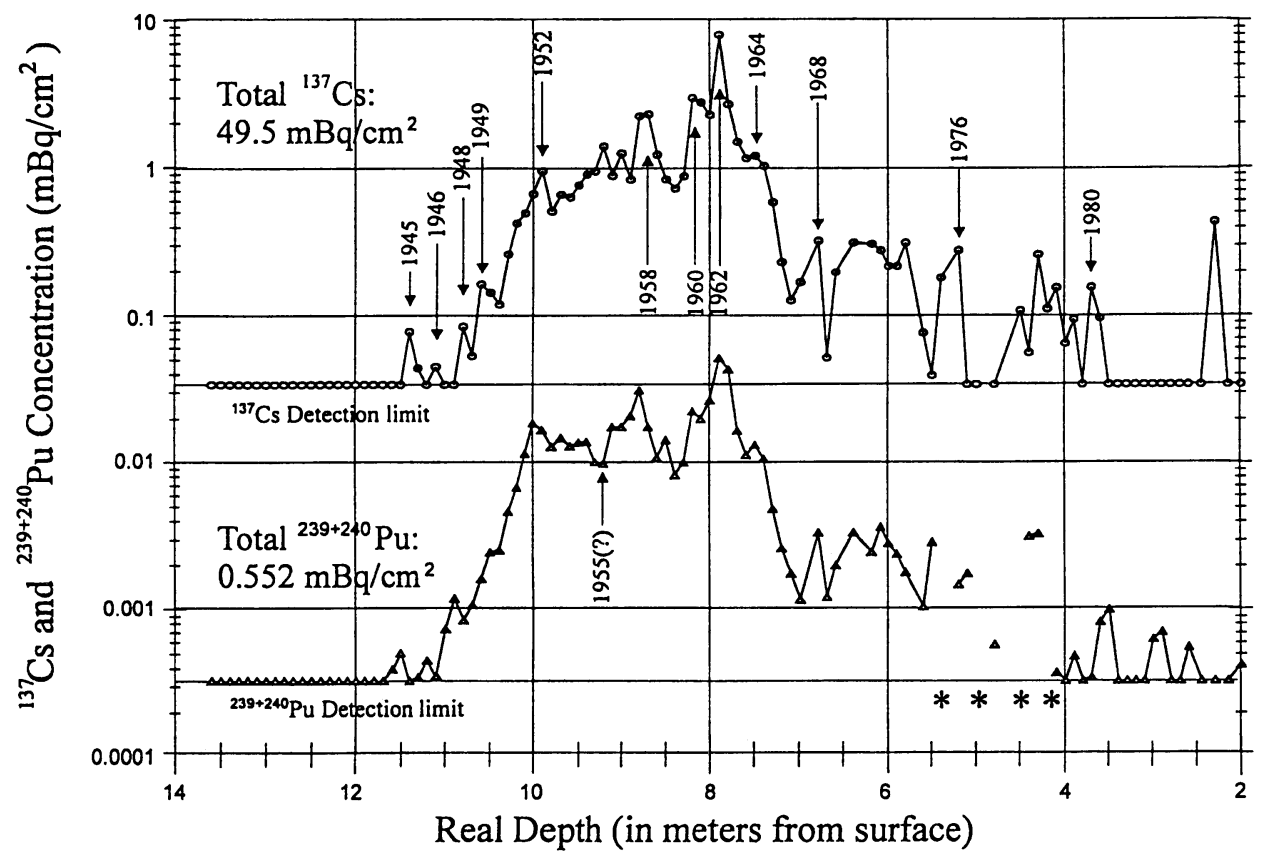

Figure $4 .{ }^{137} \mathrm{Cs}$ and ${ }^{239+240} \mathrm{Pu}$ concentrations in ice layers (age) at Ellesmere Island, NWT, Canada. (After Kudo et al. ${ }^{14}$.) 
sphere and polar ice in the last 200 years.

Recent advancements in analytical technology made it possible for artificial-radio nuclides released from nuclear explosions to be detected in Arctic ice core layers. Kudo et al. ${ }^{14)}$ measured the fission product, ${ }^{137} \mathrm{Cs}$, and the unexpended fission material, ${ }^{239+240} \mathrm{Pu}$, originating from the Nagasaki A-bomb in 1945, in the ice cores drilled on the Agassiz ice cap, Ellesmere Island, Canada. The locations of ice core site and A-bomb site are shown in Fig. 1. Fig. 4 shows nearly five decades of the chronological deposition rates of ${ }^{137} \mathrm{Cs}$ and ${ }^{239+240} \mathrm{Pu}$ ranging from 1935 to $1986 \mathrm{AD}$.

As seen in Fig. 4, the deposition rates for ${ }^{137} \mathrm{Cs}$ and ${ }^{239+240} \mathrm{Pu}$ suddenly began to appear in the ice layers from the explosions in 1945, as the nuclear age began. The authors calculated the deposition rates for ${ }^{137} \mathrm{Cs}$ and ${ }^{239+240} \mathrm{Pu}$ and found $67 \%$ of the expected amount of ${ }^{137} \mathrm{Cs}$ reached the Arctic while only $1.1 \%$ of ${ }^{239+240} \mathrm{Pu}$ reached the Arctic, which suggest that different transport mechanisms exist for various contaminants in the global transport system. It was concluded that the artificial radio nuclides from Nagasaki could be used as a global transport tracer for 1945 for tens of thousands of years to come because the half-life of ${ }^{239} \mathrm{Pu}$ is 24 , 000 years and some Canadian Arctic layers will exist more than 100,000 years.

\section{Perspective of Ice-Core Study}

As an uncertain climate lies before us, we have been studying warily how the climate system has behaved in the past. We learned that the Earth has enjoyed a steady and dependable interglacial climate for the last 8,000 years. However, recent work by European and U.S. teams, studying cores of ice from deep drillings in Greenland has shown that large, rapid changes in climate, typically lasting a few hundred to several thousand years, punctuated the longer cycles between glacial and interglacial periods.

Modern cultures have not experienced such dramatic swings. What caused them even without human intervention? What was the environmental conditions during the ice ages? It is evident that human activities have been significantly influencing the climate and environment. But what is the extent of human impact? What is the interactive mechanism of the impact? Will and how will green house gases exactly speed up and amplify the global warming? When will the next ice age come, if yes? In order to answer these questions, teams from the U.S., Europe, Japan and Australia all have deep ice core drilling projects under way. These research programs will help answer fundamental questions about the climate change in the past.

Only by obtaining the fuller understanding of the past can we begin to predict the future, including the impact of the human activities, such as the severity of greenhouse warming in the near term and, further off, can we control our future.

ACKNOWLEDGMENT: The Authors thank Drs. R. M. Koerner and D. A. Fisher, Glaciology Section, Geological Survey of Canada, for their contributions.

\section{REFERENCES}

1) J. Jouzel, et al, Extending the Vostok ice core record of palaeoclimate to the penultimate glacial period, Nature, 364, 407, 1993.

2 ) G.S. Boulton, Two cores are better than one, Nature, 366, 507, 1993.

3 ) R.M. Koerner and D.A. Fisher, A record of Holocene summer climate from a Canadian high-arctic ice core, Nature, 343, 444, 1990.

4 ) C. Vincent, et al., Snow accumulation and ice flow at Dme du Goter $(4300 \mathrm{~m})$ Mont Blanc, French Alps, J. Glaciol., 43, 513, 1997.

5 ) J.E. Dibb, et al., Northern hemisphere concentrations of methane and nitrous oxide since 1800: results from the Mt. Logan and 20D ice cores, Chemosphere, 27, 2413, 1993.

6 ) P.M. Grootes, et al., Comparison of oxygen isotope records from the GISP2 and GRIP Greenland ice cores, Nature, 366, 552, 1993.

7 ) W. Dansgaard, et al., Evidence for general instability of past climate from a $250 \mathrm{kyr}$ ice core record, Nature, 364, 218, 1993.

8 ) S.J. Johnsen, The $\delta^{18} \mathrm{O}$ record along the Greenland Ice Core Project deep ice core and the problem of possible Eemian climatic instability, J. Geophys. Res., Part C, 102, 26397, 1997.

9 ) K.C. Taylor, et al., Electrical conductivity measure ments from the GISP2 and GRIP Greenland ice cores, Nature, 366, 549, 1993. 
10) J. Zheng, et al., Solid electrical conductivity (ECM) from four Agassiz ice cores, Ellesmere Island NWT, Canada: high resolution signal and noise over the last millennium and low resolution over the Holocene, The Holocene, 8, 413, 1998.

11) T. Gulluk, et al., Simultaneous measurements of $\mathrm{CO}_{2}$, $\mathrm{CH}_{4}$, and $\mathrm{N}_{2} \mathrm{O}$ in air extracted by sublimation from Antarctica ice cores: Confirmation of the data obtained using other extraction techniques, J. Geophys. Res., Part D, 103, 15971, 1998.

12) J. Chappellaz, et al., A clue for stratigraphic disturbance in the bottom part of the Greenland Ice Core Project and the Greenland Ice Sheet Project 2 ice cores, J. Geophys. Res., Part C, 102, 26547, 1997.

13) S.K. Bartarya, et al., Environmental Radioactivity in the Arctic and Antarctic, Strand and Holm, 1993.

14) A. Kudo, et al., Global transport rates of ${ }^{137} \mathrm{Cs}$ and ${ }^{239+240} \mathrm{Pu}$ originating from the Nagasaki A-bomb in 1945 as determined from analysis of Canadian Arctic ice cores, J. Environ. Radioactivity, 40, 289, 1998.

15) R.E. Sturgeon, et al., Determination of ultratrace levels of heavy metals in Arctic snow by electrothermal vaporization inductively coupled plasma mass spectrometry, J. Anal. At. Spectrom., 8, 1053, 1993.

16) A.T. Townsend and R. Edwards, Ultratrace analysis of Antarctic snow and ice samples using high resolution inductively coupled plasma mass spectrometry, $J$. Anal. At. Spectrom., 13, 463, 1998.

17) J.P. Candelone, et al., Bismuth in recent snow from central Greenland: preliminary results, Atmos. Environ., 29, 1843, 1995.

18) G. Scarponi, Chemical Contamination of Antarctic Snow: The Case of Lead, Microchem. J., 55, 24, 1997.

19) R.B. Alley, et al., Visual-stratigraphic dating of the GISP2 ice core: Basis, reproducibility, and application, J. Geophys. Res., Part C, 102, 26367, 1997.

20) W. Dansgaard, Stable isotopes in precipitation, Tellus, $16,436,1964$

21) C. Hammer, et al., ECM stratigraphic dating of the Byrd Station ice core, Antarctica, Ann. Glaciol., 20, 115, 1994

22) M. Ram, et al., Polar ice stratigraphy from laser-light scattering: Scattering from ice, Geophysi. Res. Lett., 22, 3525, 1995.

23) M. Ram and G. Koenig. Continuous dust concentration profile of pre-Holocene ice from the Greenland Ice Sheet Project 2 ice core: Dust stadials, interstadials, and the Eemian, J. Geophys. Res., Part C, 102, 26641, 1997.

24) $\mathrm{M}$. Herron, Impurities sources of $\mathrm{F}^{-}, \mathrm{Cl}^{-}, \mathrm{NO}_{3}{ }^{-}$, and $\mathrm{SO}_{4}{ }^{2-}$ in Greenland and Antarctic precipitation, $J$. Geophys. Res., Part D, 87, 3052, 1982.

25) S. Whitlow, et al., A comparison of major chemical species input timing and accumulation at South Pole and Summit, Greenland, Atmos. Environ., 26, 2045, 1992.

26) A. Sigg and A. Neftel, Seasonal variations in hydrogen peroxide in polar ice cores, Ann. Glaciol., 10, 157, 1988.

27) D. Lal, et al., Measurements of in situ $14 \mathrm{C}$ concentrations in Greenland Ice Sheet Project 2 ice covering a 17 -kyr time span: Implications to ice flow dynamics, $J$.
Geophys. Res., Part C, 102, 26505, 1997.

28) C. Schott, et al., Predicted time-scales for GISP2 and GRIP boreholes at Summit, Greenland, J. Glaciol., 38, 162, 1992

29) E.E. Picciotoo and S. Wilgain, Fission product in Antarctic snow, a reference level for measuring accumulation, J. Geophys. Res., Part D, 68, 5965, 1963.

30) J.D. Devine, et al., Estimates of sulphur and chlorine yield to the atmosphere from volcanic eruptions and potential climatic effects, J. Geophys. Res., Part D, 89, 6309, 1984.

31) M. Legrand and C. Kirchner, A 200 year continuous record of volcanic $\mathrm{H}_{2} \mathrm{SO}_{4}$ in the Antarctic ice sheet, Nature, 327, 671, 1987.

32) H.B. Clausen, et al., in Ice core studies of global biogeochemical cycles, NATO ASI Series I 39, R.J. Delmas, editor, 1995, pp175.

33) D.A. Fisher, et al., Holocene climatic records from Agassiz Ice Cap, Ellesmere Island, NWT, Canada, The Holocene, 5, 19, 1995.

34) J.W.C. White, Don't touch that dial, Nature, 364, 186, 1993.

35) G. Bond, et al., Correlations between climate records from North Atlantic sediments and Greenland ice, Nature, 365, 143, 1993.

36) GRIP project members, Climate instability during the last interglacial period recorded in the GRIP ice core, Nature, 364, 203, 1993.

37) D.L. Morse, et al., Ice age storm trajectories inferred from radar stratigraphy at Taylor Dome, Antarctica, Geophys. Res. Lett., 25, 3383, 1998.

38) M.C. Leuenbergen, et al., Modeling of the signal transfer of seawater $\delta^{18} \mathrm{O}$ to the $\delta^{18} \mathrm{O}$ of atmospheric oxygen using a diagnostic box model for the terrestrial and marine biosphere, J. Geophys. Res., Part C, 102, 26841, 1997.

39) D. Dahl-Jensen, et al., Flow properties of the ice from the Greenland Ice Core Project ice core: The reason for folds? J. Geophys. Res., Part C, 102, 26831, 1997.

40) J. Jouzel, et al., Climatic interpretation of the recently extended Vostok ice records, Climate Dynamics, 12 , $513,1996$.

41) J. Schwander, et al., Age scale of the air in the summit ice: Implication for glacial-interglacial temperature change, J. Geophys. Res., Part D, 102, 19483, 1997.

42) M. Anklin, et al., $\mathrm{CO}_{2}$ record between 40 and $8 \mathrm{kyr}$ B.P. from the Greenland Ice Core Project ice core, J. Geophys. Res., Part C, 102, 26539, 1997.

43) H.J. Smith, et al., The $\mathrm{CO}_{2}$ concentration of air trapped in Greenland Ice Sheet Project 2 ice formed during periods of rapid climate change, J. Geophys. Res., Part C, 102, 26577, 1997.

44) G.A. Zielinski, et al., Volcanic aerosol records and tephrochronology of the Summit, Greenland, ice cores, J. Geophys. Res., Part C, 102, 26625, 1997.

45) S. Baumgartner, et al., Chlorine 36 fallout in the Sum mit Greenland Ice Core Project ice core, J. Geophys Res., Part C, 102, 26659, 1997.

46) R.C. Finkel, et al., Beryllium 10 concentrations in the GISP2 ice core from 3-40 ka, J. Geophys. Res., Part C, 102, 26699, 1997. 
47) P. Laj, et al., Distribution of $\mathrm{Ca}, \mathrm{Fe}, \mathrm{K}$ and $\mathrm{S}$ between soluble and insoluble material in the Greenland Ice Core Project ice core, J. Geophys. Res., Part C, 102, 26615, 1997.

48) T.D. Jickells, et al., trace elements in snow samples from the Scottish highlands: sources and dissolved/ particulate distributions, Atmos. Environ., 26A, 393, 1992.

49) C. Barbante, et al., Direct determination of heavy metals at picogram per gram levels in Greenland and
Antarctic snow by double focusing inductively coupled plasma mass spectrometry, J. Anal. At. Spectrom., 12, 925, 1997.

50) C.F. Boutron, et al., Past and recent changes in the large scale tropospheric cycles of lead and other heavy metals as documented in Antarctic and Greenland snow and ice: a review, Geochim. Cosmochim. Acta, 58, 3217, 1994.

51) J.L. Jaffrezo, et al., Polycyclic aromatic hydrocarbons in the polar ice. Atmos. Environ., 28A, 1139, 1994.

\section{北極アイスコア：過去の地球環境解明と将来予測}

\section{工 藤＼cjkstart章（京都大学原子炉実験所）}

本稿は, 氷河やアイスコアを研究する専門家を対象に書かれたものではなく, 環境技術分野の一般的な 読者を対象としている. 地球環境の長い履歷が, 現在も氷河として極地に凍結保存されていることの神秘 性, その科学的重要性に力点を置いたレビュ一論文である. 氷河から得られる過去の地球環境情報につい て，50編以上の文献を引用して論じており，そこから得られる情報は，最近 20 年の急激な分析化学技術の 進歩で, その情報量が急増すると共に, これまで想像もされなかった地球環境の履歴を克明に解明してい る. 当然のことながら人間は, 与えられた地球環境の中でしか生きられない. 過去 8000 年間を振り返ると, 地球表面の温度は, それまでの 25 万年間の地球環境の気温と較べ, 驚くほど安定していること.この気温 安定のために，人間は，それまでの狩猟・採取の生活から，農業の生活へと変えることができたこと．そ して農業の生活は, 人間にゆとりと富を与え, エジプトのピラミッドからローマへ，そして今日の文明を 発達させることができたことの基本的理由を説明している．このアイスコアからの地球環境の正確な履歴 の発見は，最近 10 年間の世界最大の発見とさえ言われている.

アイスコアからの地球環境の正確な履歴の発見の中には，他にも驚くべき事実があった．今の間氷河期 （最後の水河期から現在まで）より一つ前の間水河期（ 9 -14万年昔）における地球表面の温度に関する 発見である.この間水河期の平均気温は， 1 万 1640 年昔から始まった今の間氷河期より高かったことは, 湖・海洋の底土の分析等から推測されていた. しかし, その平均気温は高くても, それが急激に変動して いたことは, グリーンランドのアイスコア分析結果が得られるまでは，まったく想像だにされていなかっ た.グリーンランドのアイスコア分析結果は, 10 年間で $7{ }^{\circ} \mathrm{C}$ 気温変化を示しているのである.もし現在, 10 年間で $7^{\circ} \mathrm{C}$ 気温変化がこの地球上で起こるとすれば，地球の全人口の半数は食料不足で死亡すると予 測されている.ただし, $7{ }^{\circ} \mathrm{C}$ 気温変化が 100 年間で起こる場合には, 現在の農業技術をもってすれば, 充 分に対処できると考えられている。

残念なことは，（1）なぜ過去8000年間の地球表面の温度は, 驚くほど安定しているのか？その原因は何 か?，（2）1つ前の間水河期（9-14万年昔）の地球表面温度は，なぜ急激に変動したのか? その変動を 示す兆候はなかったか? などの疑問に対して, 現時点では何の手がかりも無いことである. 現在, 世界の 氷河学者・微量分析学者は, これらの手がかりを得ようと, 必死の努力を続けている. 本レビュー論文で は, 我々のグループがカナダ領北極エレズメア島氷河で採掘したアイスコアを分析して得られたデータ（最 近の国際学会誌に発表済み）も加え, 氷の中に凍結保存されている過去 1 万年間の詳細なデー夕を解説し た.また，最近のデータとしては，1945年の長崎原爆によるプルトニウムが，北極に降下した量を，1945 年の氷層から分析した結果も併せて解説した。極微量分析技術が今日ほど発達していなかった 1950 年以前 のデータは存在せず, 我々のデータが世界最初のものとなっている. 